Arab Univ. J. Agric. Sci., Ain Shams Univ., Cairo, 14(1), 427-438, 2006

\title{
EFFECT OF VITAMIN ADDITIVE AND COLONY MAN- AGEMENT ON HONEY BEE PERFORMANCE
}

\section{[28]}

\author{
Elbassiouny $^{1}$, A.M.
}

\begin{abstract}
The effect of both beekeeping processes (compressed bees $\mathbf{C b}$ and traditional beekeeping $\mathbf{T b}$ ) and food diets (vitamins mixed with pollen grains, pollen grains only and plain sugar syrup) on the colony build up were studied during February April, 2004, at the apiary belonging to Faculty of Agriculture, Ain Shams University. Feeding colonies with supplementary vitamins plus pollen grains resulted after four brood cycles significantly high daily rates of rearing brood (523 and 434 brood cells for $\mathrm{Cb}$ and $\mathrm{Tb}$, respectively) and drawing combs (4.31 and 1.61 combs for $\mathrm{Cb}$ and $\mathrm{Tb}$, respectively) compared to either unique pollen grains (432 and 338 brood cells and 3.2 and 1.19 combs for $\mathrm{Cb}$ and $\mathrm{Tb}$, respectively) or plain sugar syrup (313 and 219 brood cells and 2.1 and 0.79 combs for $\mathrm{Cb}$ and $\mathrm{Tb}$, respectively). On the other hand, the worker's longevity recorded vice versa which were 21.2 26.2, 23.8 days for colonies fed on vitamins plus pollen grains, pollen grains and sugar syrup, respectively. The colonies which fed on vitamins plus pollen grains, pollen grains and plain sugar syrup, their workers were hoarded 236, 220 and $191 \mathrm{mg}$ of sugar syrup / 3 days, respectively.
\end{abstract}

Keywords: Honey bee, Apis mellifera, Vitamins, Pollen, Drawing combs, Brood, Hoarding - Longevity

\section{INTRODUCTION}

The normal development and growth of honey bee colony is often hampered by an insufficient pollen supply. Honey bees use the protein portion of pollen mainly to provide structural elements of muscles, glands and other tissues (Brouwers, 1983 and Ricciardelli et al 1987). Therefore, bees tend to collect pollen (Hellmich \& Rothenbuhler, 1986 and Stabentheiner \& Kaslberger, 1997), but the weather conditions (Wille, 1985 and Blaschon et al 1999), floral origin (Diaz et al 1996 and Serra \& Escala, 1997), the genetic differentiation between bee races (Hellmich, 1983) and the empty space of cells (Eischen et al 1983) play an important role for foraging bees to collect and hoard pollen.

Pollen grains from different sources vary in their nutritional values, especially vitamins (Imdorf et al 1998; Mladenovic et al 1999 and Karacaoglu et al

1- Plant Protection Department, Faculty of Agriculture, Ain Shams University, Shoubra El-Kheima, Cairo, Egypt

(Received September 21, 2005)

(Accepted October 8, 2005) 
2003) and so far their biological effects (Herbert et al 1985 and Funari et al 2003). Consequently, the emerging bee is directly influenced by the pollen consumption of the nurse bees (Zhou et al 1991). It is known that the mixture of pollen offered complete diet for the bees. So, either the dearth of pollen or pollen from one source is result insufficient vitamins for the bees. Therefore vitamins must be supplied in the proper balance with other food components, since it was shown that the vitamins requirements are related to the dietary protein level (Dietz, 1975).

The present study aimed to compare the effect of pollen and certain vitamins on the build-up of honey bee colonies to be ready for the main honey crop (clover) especially after relatively poor spring build-up.

\section{MATERIAL AND METHODS}

The present work was conducted in the apiary belonging to Faculty of Agriculture, Ain Shams University during February - April, 2004. Thirty free flying colonies of nearly same strength each was (five combs each) headed with newly open mated Carniolan queen were divided into two sets. Bees in the first set colonies were compressed on two combs only, while those in the second set were received traditional beekeeping. Each colony in both sets was provided with frame of wax foundation and the surplus of foundations were added ad libitum as the time progress as the colony needed. The colonies each set were divided into three groups; each group contained five colonies (replicates). Colonies of each group were offered one of the following food regimes:
A: sugar syrup (1:1) plain.

B: sugar syrup (1:1) plus pollen grains $10 \%$.

C: sugar syrup (1:1) plus pollen grains $10 \%$ and fortified with Vitamins.

One liter of $50 \%$ sugar syrup was offered to each experimental colony of group A. The available pollen loads, which previously collected by the bees (mostly corn), were crushed in blender then added to the sugar syrup by weight just before offered to the bees in colony of group B.

Medicinal vitamins (SUPRAVIT) capsule, each contains: Vit.A (2000iu), Vit. $\mathrm{D}_{3}$ (200iu), Vit. H (10mg), Vit. $\mathrm{B}_{1}$ (15mg), Vit.B (3mg), Vit.B ${ }_{6}$ (2mg), Vit. $_{12}$ (5ug (micro gram)), Biotin (3ug), Calcium D-pantothenate (3mg), Vit.C (50mg), Folic acid (25ug), Nicotinamide (15mg), Amio benzoic acid (50mg), LLysine (20mg), Rutin (10mg), Fe (10mg), k (2mg), Cu (1mg), Zn(1mg), Mg(1mg), $\mathrm{Ca}(5 \mathrm{mg})$, Pollen extract $(16.6 \mathrm{mg})$ were used. Each colony of group $\mathrm{C}$ was received one capsule in each feeding time, which prepared by dissolving it in the sugar syrup just before offering to the bees. The different type of food regimes were provided to each colony one time weekly.

The effect of the fore- mentioned nutritional treatments on the colony build up was measured by counting the worker sealed broods and the drawing cells of wax foundation at 13-day interval and calculating their daily rates of both brood rearing and drawing the cells of wax foundation. The percentage of drawing combs was estimated by dividing the area measured on the total area of both sides of wax foundation which represent 1539 $\mathrm{cm}^{2} / 5986$ cells $\left(3.889\right.$ cells $\left./ \mathrm{cm}^{2}\right)$. 
The longevity of the emerged workers after feeding the previous diet regimes was obtained as follows: sealed worker brood comb from each replicates of each feeding groups were kept separately in an incubator at $33{ }^{\circ} \mathrm{C}$ and $70 \%$ R.H. until emerging. 100 workers from each replicate of each feeding regime were kept just after emergence in wooden cage with screen sides $(21 \times 12 \times 8 \mathrm{~cm})$ provided from its top with a piece of wax comb to hold the bees on it. Each cage was also provided with a conical glass with muslin cover containing 50\% sugar solution and situated upside down to let the bees suck the syrup from it. Daily observation was made to count the died bees in the successive day until all bees were died.

To study hoarding behaviour, 100 workers from those found on honey combs of each replicate from each feeding treatments were taken, anaesthised and placed in cages (previously described). After three days, the amounts of transferred sugar syrup were recorded, thereafter calculating the amount per bee.

\section{RESULTS AND DISCUSSION}

\section{Brood rearing activity}

As seen in Table (1) and Fig.(1), highly significant variance between the three feeding diet groups after each brood cycle was found in compressed bee colonies. The daily brood rearing after offering plain sugar syrup only averaged 181.2, 219.8, 269.6 and 313.6 brood cells/day after first, second, third and fourth brood cycles, respectively. Additional of pollen grains $(10 \%)$ to the sugar syrup caused an obvious increase in the daily brood rearing, i.e., 226.6, 285.6, 345.8 and 432.2 brood cells / day after first, second, third and fourth brood cycles, respectively. In case of bees received pollen grains $(10 \%)$ fortified with supplementary vitamins, the daily brood rearing reached the maximum (249.8, 336.2, 416.2 and 523 brood cells/day after first, second, third and fourth brood cycles, respectively).

In case of traditional beekeeping, Table (2) and Fig. (1), the lowest daily brood rearing were 109.4, 145.8, 187.6 and 219.2 brood cells / day for the first, second, third and fourth brood cycles, respectively for plain sugar syrup; 171.8, 214.2, 264.4 and 318.4 brood cells / day, respectively after adding pollen grains $(10 \%)$ and 196.2, 273.2, 342.6 and 434.2 brood cells / day, respectively, when bees were received pollen grains $(10 \%)$ fortified with supplementary vitamins.

The present data coincide with those of Imdorf et al (1998) and Karacaoglu et al (2003) who reported that, the bees' need to complete diet either founded in mixture of pollen or fortify the pollen grains (if from one source) with vitamins to rear brood. Moreover, the beekeeping processes play an important role for regulating conditions inside the hive to obtain high colony build-up.

\section{Drawing the cells of wax foundation}

Generally, compressed bees on two combs in the colony encourage the workers to draw more cells of wax foundation to offer suitable space for egg laying by the queen. Data in Table (3) and Fig. (2) show that, in case of compressed bees, workers started to draw cells / day with high numbers, but with significant variation among groups according to feeding diets. In the $1^{\text {st }}$ brood cycle means of 294.7, 419 and 612.4 drawn cell / day 
Table 1. Average daily rates of brood rearing during four brood cycles after feeding three different food diets in bees compressed on low number of combs

\begin{tabular}{|c|c|c|c|c|c|}
\hline \multirow{2}{*}{ Treatments } & \multirow{2}{*}{ Rep. } & \multicolumn{4}{|c|}{ Brood cycles } \\
\hline & & $1^{\mathrm{st}}$ & $2^{\text {nd }}$ & $3^{\text {rd }}$ & $4^{\text {th }}$ \\
\hline \multirow{7}{*}{ Plain sugar syrup } & 1 & 149 & 198 & 227 & 283 \\
\hline & 2 & 197 & 235 & 287 & 312 \\
\hline & 3 & 207 & 257 & 311 & 361 \\
\hline & 4 & 168 & 201 & 254 & 291 \\
\hline & 5 & 185 & 208 & 269 & 315 \\
\hline & Mean & $181.2^{\mathrm{A}}$ & $219.8^{\mathrm{A}}$ & $269.6^{\mathrm{A}}$ & $313.6^{\mathrm{A}}$ \\
\hline & \pm S.D. & \pm 20.7 & \pm 22.8 & \pm 29.9 & \pm 26.9 \\
\hline \multirow{6}{*}{$\begin{array}{c}\text { Sugar syrup } \\
+ \text { Pollen }(10 \%)\end{array}$} & 1 & 221 & 303 & 362 & 438 \\
\hline & 2 & 227 & 312 & 391 & 481 \\
\hline & 3 & 298 & 274 & 318 & 416 \\
\hline & 4 & 200 & 278 & 349 & 444 \\
\hline & 5 & 187 & 261 & 309 & 392 \\
\hline & Mean & $226.6^{\mathrm{B}}$ & $285.6^{\mathrm{B}}$ & $345.8^{\mathrm{B}}$ & $432.2^{\mathrm{B}}$ \\
\hline \multirow{8}{*}{$\begin{array}{c}\text { Sugar syrup } \\
+ \text { Pollen }(10 \%) \\
+ \text { + Vitamins }\end{array}$} & \pm S.D. & \pm 38.5 & \pm 23.9 & \pm 29.8 & \pm 26.7 \\
\hline & 1 & 234 & 332 & 418 & 501 \\
\hline & 2 & 205 & 294 & 392 & 493 \\
\hline & 3 & 289 & 375 & 451 & 557 \\
\hline & 4 & 295 & 366 & 424 & 542 \\
\hline & 5 & 226 & 314 & 396 & 522 \\
\hline & Mean & $249.8^{\mathrm{B}}$ & $336.2^{\mathrm{C}}$ & $416.2^{\mathrm{C}}$ & $523^{\mathrm{C}}$ \\
\hline & \pm S.D. & \pm 35.8 & \pm 30.6 & \pm 24.3 & \pm 21.1 \\
\hline $\mathrm{F}$ & & $6.664 * *$ & $22.547 * *$ & $33.893 * *$ & $39.118 * *$ \\
\hline L.S.D. & & \pm 50.2 & \pm 37.9 & \pm 42.1 & \pm 40.1 \\
\hline
\end{tabular}


Table 2. Average daily rates of brood rearing during four brood cycles after feeding three different food diets in bees received traditional beekeeping

\begin{tabular}{|c|c|c|c|c|c|}
\hline \multirow{2}{*}{ Treatments } & \multirow{2}{*}{ Rep. } & \multicolumn{4}{|c|}{ Brood cycles } \\
\hline & & $1^{\mathrm{st}}$ & $2^{\text {nd }}$ & $3^{\text {rd }}$ & $4^{\text {th }}$ \\
\hline \multirow{7}{*}{ Plain sugar syrup } & 1 & 135 & 185 & 214 & 261 \\
\hline & 2 & 117 & 169 & 204 & 225 \\
\hline & 3 & 88 & 105 & 156 & 189 \\
\hline & 4 & 114 & 146 & 190 & 215 \\
\hline & 5 & 93 & 124 & 174 & 206 \\
\hline & Mean & $109.4^{\mathrm{A}}$ & $145.8^{\mathrm{A}}$ & $187.6^{\mathrm{A}}$ & $219.2^{\mathrm{A}}$ \\
\hline & \pm S.D. & \pm 17.1 & \pm 29.0 & \pm 20.8 & \pm 24.0 \\
\hline \multirow{5}{*}{$\begin{array}{c}\text { Sugar syrup } \\
+ \text { Pollen }(10 \%)\end{array}$} & 1 & 198 & 255 & 295 & 410 \\
\hline & 2 & 181 & 226 & 294 & 278 \\
\hline & 3 & 141 & 187 & 215 & 287 \\
\hline & 4 & 162 & 201 & 248 & 305 \\
\hline & 5 & 177 & 202 & 270 & 312 \\
\hline \multirow{9}{*}{$\begin{array}{c}\text { Sugar syrup } \\
+ \text { Pollen }(10 \%) \\
+ \text { Vitamins }\end{array}$} & Mean & $171.8^{\mathrm{B}}$ & $214.2^{\mathrm{B}}$ & $264.4^{\mathrm{B}}$ & $338.4^{\mathrm{B}}$ \\
\hline & \pm S.D. & \pm 19.2 & \pm 30.2 & \pm 23.9 & \pm 39.2 \\
\hline & 1 & 209 & 304 & 354 & 463 \\
\hline & 2 & 171 & 219 & 285 & 370 \\
\hline & 3 & 218 & 326 & 386 & 482 \\
\hline & 4 & 184 & 246 & 335 & 426 \\
\hline & 5 & 199 & 271 & 353 & 430 \\
\hline & Mean & $196.2^{\mathrm{C}}$ & $273.2^{\mathrm{C}}$ & $342.6^{\mathrm{C}}$ & $434.2^{\mathrm{C}}$ \\
\hline & \pm S.D. & \pm 16.9 & \pm 38.5 & \pm 33.1 & \pm 38.3 \\
\hline $\mathrm{F}$ & & $19.39 * *$ & $14.387 * *$ & $22.54 * *$ & $21.639 * *$ \\
\hline L.S.D. & & \pm 21.3 & \pm 46.6 & \pm 43.9 & \pm 58.1 \\
\hline
\end{tabular}




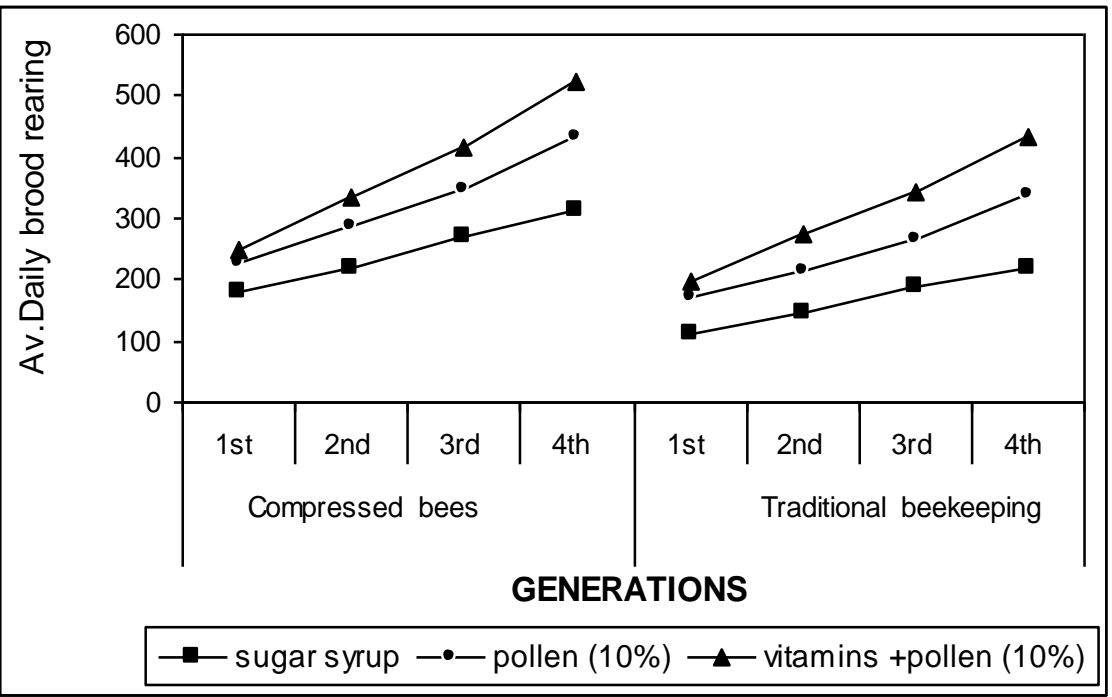

Fig. 1. Comparison between average daily brood rearing rates in compressed bees or those received traditional beekeeping, all were fed with different types of food

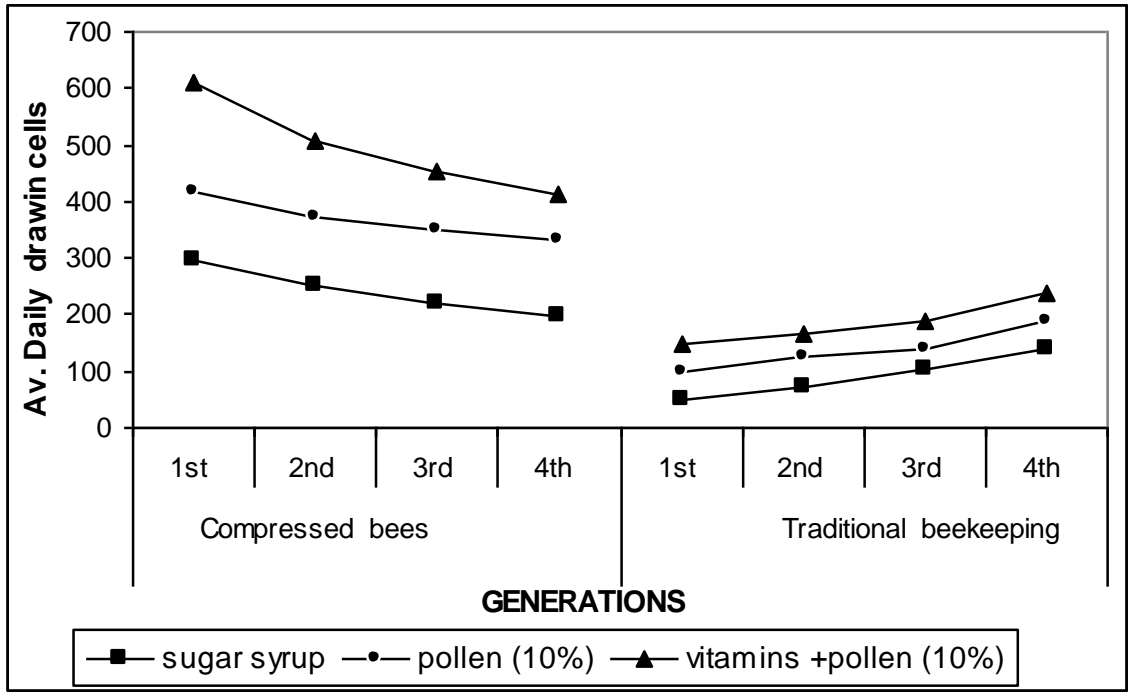

Fig. 2. Comparison between average daily drawing cells in compressed bees or those received traditional beekeeping, all were fed with different types of food. 
were recorded for plain sugar syrup, pollen $(10 \%)$ and pollen grains $(10 \%)$ fortified with vitamins, respectively. As the time progress till the $4^{\text {th }}$ brood cycle, the number of drawn cells / day decreased and reached 198, 331.5 and 414.4 for the three respective mentioned groups. This may be due to the need of colony for combs and increase the number of drawn combs which reached $2.1,3.2$ and 4.31 drawn combs for the three mentioned groups, respectively (Fig. 3).

On the other hands, in the set of colonies which received traditional beekeeping, more space for queens to lay eggs was found. The number of drawn cells / day in the $1^{\text {st }}$ brood cycle was $50.6,96.7$ and 147.3 for plain sugar syrup, pollen $(10 \%)$ and pollen grains $(10 \%)$ fortified with vitamins, respectively (Table 4 and Fig. 2). As the time progress till the $4^{\text {th }}$ brood cycle, the number of drawn cells / day increased gradually to reach 138.1, 188.8 and 239.4 for the three mentioned groups, respectively.

The total numbers of drawn combs were still lower than that in case of compressed bees as $0.79,1.19$ and 1.61 drawn combs / day were recorded for the three mentioned groups, respectively (Fig. 3).

The data indicate that bees tend to regulate their effort for colony performance according to its needs.

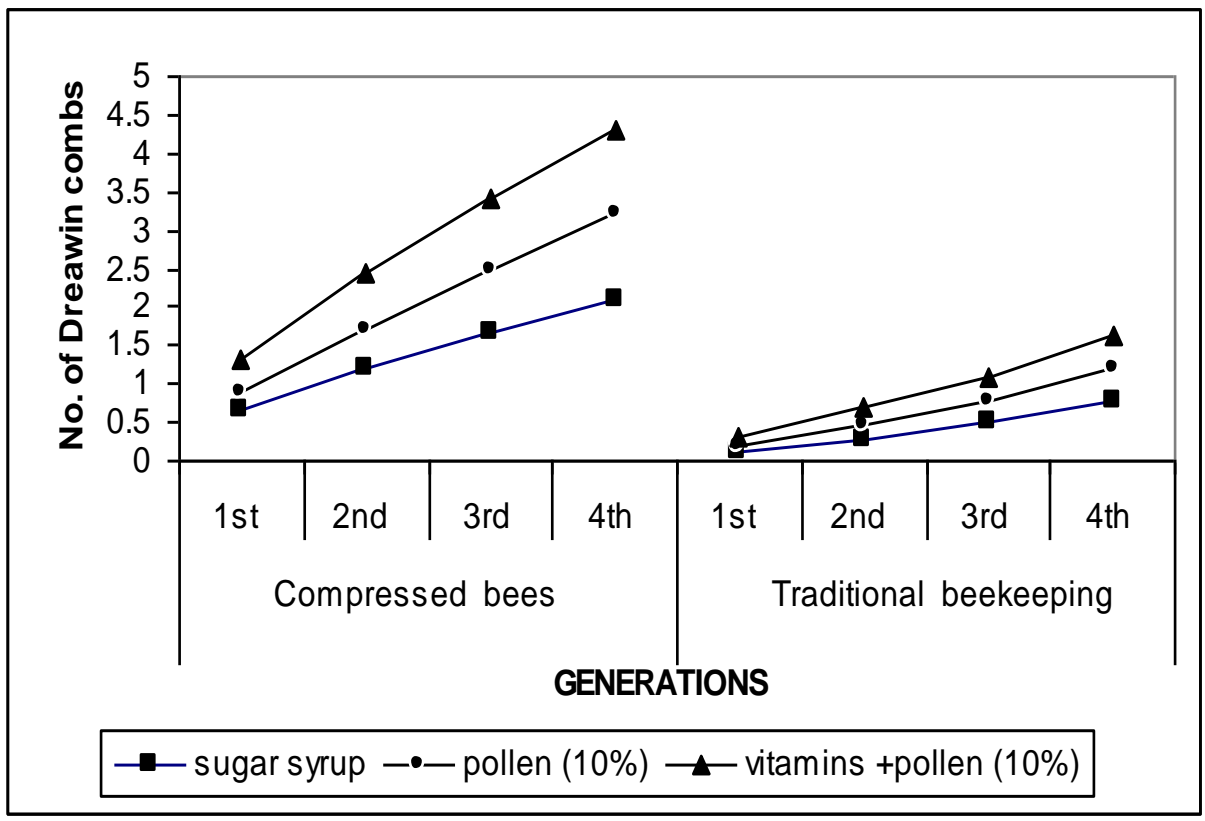

Fig. 3. Comparison between average number of drawing combs in compressed bees or those received traditional beekeeping, all were fed with different types of food 
Arab Univ. J. Agric. Sci., 14(1), 2006 


\section{Worker's longevity}

The life span of the newly emerged worker bee, showed significant differences among food diets offered to the worker bees (Table 5). The longest longevity was recorded when workers were fed on pollen $10 \%$ (26.2 days) followed by those fed on plain sugar syrup (23.8 days). Workers fed on supplementary vitamins significantly came the last in order (21.2 days). The vitamins encourage the bees to fast build up their colony; it decreased their life span (Dietz, 1975).

Table 5. Average worker's longivitie (days) after feeding their colonies on three different food diets.

\begin{tabular}{|cccc|}
\hline Replicates & $\begin{array}{c}\text { Plain } \\
\text { sugar } \\
\text { syrup }\end{array}$ & $\begin{array}{c}\text { Sugar } \\
\text { syrup } \\
+ \text { Pollen } \\
(10 \%)\end{array}$ & $\begin{array}{c}\text { Sugar syrup } \\
+ \text { Pollen }(10 \%) \\
\text { +Vitamins }\end{array}$ \\
\hline 1 & 23 & 23 & 20 \\
2 & 26 & 25 & 22 \\
3 & 21 & 29 & 23 \\
4 & 24 & 28 & 19 \\
5 & 25 & 26 & 22 \\
Mean \pm S.D. & $23.8 \pm 1.9^{\text {b }}$ & $26.2 \pm 2.1^{\text {a }}$ & $21.2 \pm 1.6^{\text {c }}$ \\
\hline F & \multicolumn{3}{|c}{$6.136^{* *}$} \\
L.S.D. & \multicolumn{3}{|c}{. 2.031} \\
\hline
\end{tabular}

\section{Hoarding behaviour}

The hoarding behaviour as expressed by the quantity of sugar syrup transferred by caged worker bees in limit time, which use, as an indicator for the tendency of free flying workers to gather nectar is an economically important characteristic behaviour. Data in Table (6) show that the bees whose fed on vitamins plus pollen $10 \%$ transferred highest amount of sugar syrup through 3 days $(236 \mathrm{mg} /$ bee) followed by those fed on pollen $10 \%$ (220 mg / bee) with no significant differences between them. The plain sugar syrup significantly came the last in order (191 mg / bee).

From the fore - mentioned results, it could be concluded that food requirements as a complete diet play an important role for colony build up. The lack of vitamins due to unique pollen source has negative effect; therefore it must be add to the food offered to the colony which encourages the worker bees to be more active either for brood rearing or drawing wax foundation. Moreover, the beekeeping process also very important for colony performance which encourage the bees to thermoregulate their hive and arrange their nest.

Table 6. Average worker's hoarding behaviour (bee / 3 days mg) after feeding their colonies on three different food diets.

\begin{tabular}{|cccc|}
\hline Replicates & Plain sugar syrup & $\begin{array}{c}\text { Sugar syrup } \\
\text { + Pollen }(10 \%)\end{array}$ & $\begin{array}{c}\text { Sugar syrup } \\
\text { +Pollen }(10 \%)+\text { Vitamins }\end{array}$ \\
\hline 1 & 182 & 251 & 270 \\
2 & 171 & 197 & 222 \\
3 & 203 & 205 & 251 \\
4 & 209 & 230 & 230 \\
5 & 190 & 217 & 207 \\
Mean \pm S.D. & $191 \pm 13.8^{\mathrm{b}}$ & $220 \pm 19.1^{\mathrm{a}}$ & $236 \pm 24.8^{\mathrm{a}}$ \\
\hline F & & $4.629 *$ & \\
L.S.D. & & \pm 26.8 & \\
\hline
\end{tabular}




\section{REFERANCES}

Blaschon, B.; H. Guttenberger; N. Hrassingg; K. Crailsheim (1999). Impact of bad weather on the development of the broodnest and pollen stores in a honeybee colony (Hymenoptera: Apidae). EntomologiaGeneralis. 24(1): 49-60.

Brouwers, E.V. (1983) .Activation of the hypopharyngeal glands of honeybees in winter J. Apic. Res. 22(3): 137-141.

Diaz, L.E; G.E. Fernandez; C.C. Alvarez and O.P. Saa (1996). Contribution to the understanding of the floral origin and chemical composition of bee- collected pollen in Galicia, Spain. Boletin de la Real Sociedad Espanola de Historia Natural, Seccion Biologica. 92: (1): 4,195-202.

Dietz, A. (1975). Nutrition of the adult honey bee. The Hive and the Honey Bee pp. 137-140. Dadant and Sons. Hamilton, Illinois, USA.

Eischen, F.A.; W.C. Rothenbuhler; J.M. Kulincevic (1983). Brood rearing associated with a range of worker-larva ratios in the honeybee. J. Apic. Res. 22(3): 163-168.

Funari, S.R.; H.C. Rocha; J.M. Sforcin; H.G. Filho; P.R. Curi; S.M. Dierckx and R.O. Orsi (2003). Bromatological and mineral compositions of collected pollen for Africanized honey bee (Apis mellifera L.) in Botucatu, Sao Paulo State. Archivos Latinoamericanos de Produccion Animal. 11 (2): 87-93.

Hellmich, R.L. (1983). Genetic and behavior analyses of pollen hoarding in the honey bee Apis mellifera L. Ohio State Univ., Columbus, USA Bibliographic citation: $p .109$.
Hellmich, R.L.; W.C. Rothenbuhler (1986 ) .Relationship between different amounts of brood and the collection and use of pollen by the honey bee (Apis mellifera L.). Apidologie., 17(1): 13-20.

Herbert, E.W.; J.T. Vanderslice; D.J. Higgs (1985). .Effect of dietary vitamin $\mathrm{C}$ levels on the rate of brood production of free-flying and confined colonies of honey bees. Apidologie. 16(4): 385-394.

Imdorf, A.; M. Rickli; V. Kilchenmann; S. Bogdanov and $H$. Wille (1998). Nitrogen and mineral constituents of honey bee worker brood during pollen shortage.Apidologie, 29(4): 315-325.

Karacaoglu, M.; H.V. Gencer and A.U. Koc (2003). Effects of supplemental feeding on brood production and honey yield of honey bee) Apis mellifera L.) colonies in the Aegean Region. J. Anim. Produc. 44(2): $47-54$.

Mladenovic, M.; V. Mladan and V.N. Dugalic (1999). Effect of vitaminmineral preparation on development and productivity of bee colonies. Acta Veterinaria Beogarad. 49(2-2): 177-184. Ricciardelli, D.; G. Albore; B.M. Battaglini; N. Isidoro (1987). Development of the hypopharyngeal glands in honeybees fed on pollens or pollen substitutes. Apicoltura No. 3: 1536.

Serra, B.J. and J.R. Escola (1997). Nutrient composition and microbiological quality of honey bee collected pollen in Spain. J. Agric. and Food Chemistry. 45(3): 725 -732.

Stabentheiner, A.; G. Kastberger (1997). .Seasonal and daily variation of honeybee dancing temperature under constant feeding conditions. Apidologie. 28(6): 385-398. 
Wille, H. (1985). Further results on the brood rhythm of honeybee colonies.

Schweizerische-Bienen-Zeitung. 108(7): 327-343.
Zhou-R; Y. Tang; X. Zhou (1991). Nutritional evaluation of proteins of honeybee larvae. Shipin-Kexue, 138: 512.

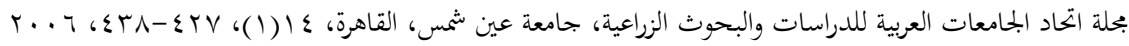
تأثير اضافة الفيتامينات وادارة الطائفة على أداء نحل العسل

$[r \wedge]$

\section{عادل محمد البسيونى '}

ا ـ قسم وقاية النبات- كلية الزراعة - جامعة عين شمس - شبرا الخيمة- القاهرة- مصر

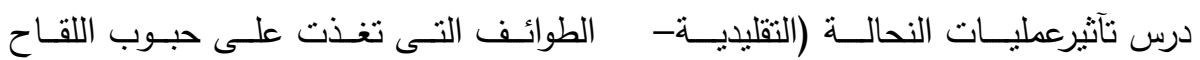

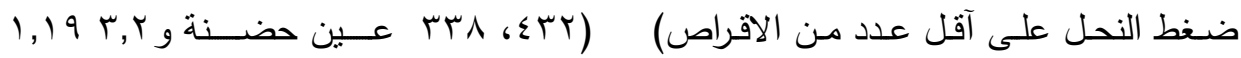

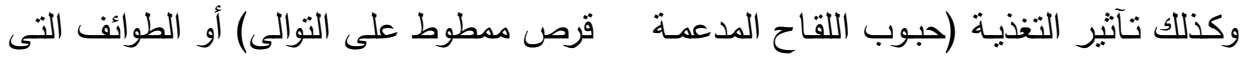

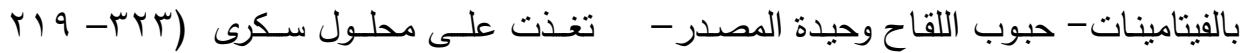

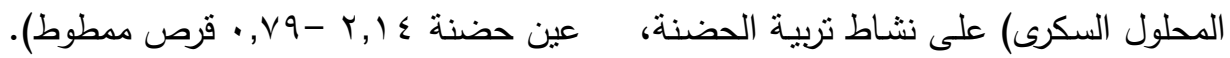

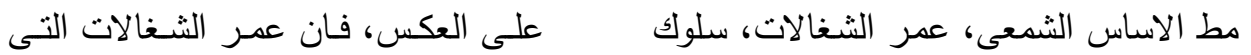

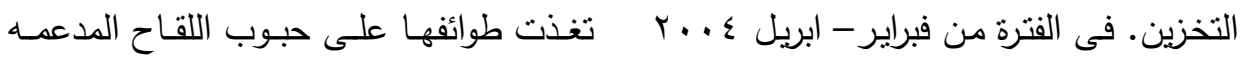

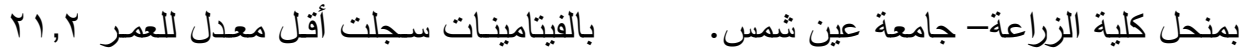

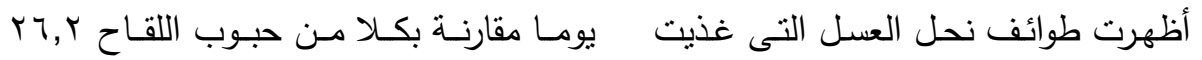

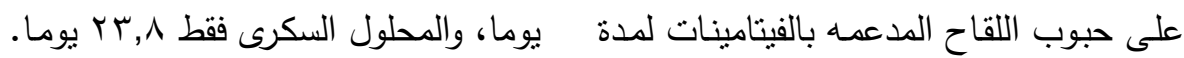
ع دورات حضنه فروقا معنويه واضحة فى كما اظهرت نتائج سلوك تخزين المحلول

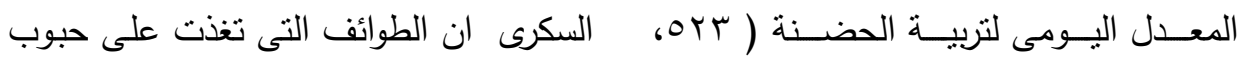

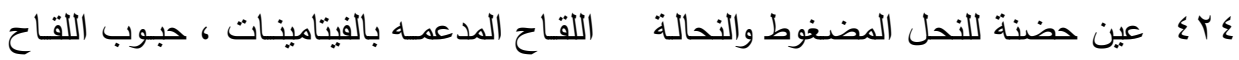

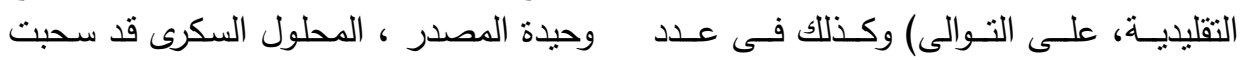

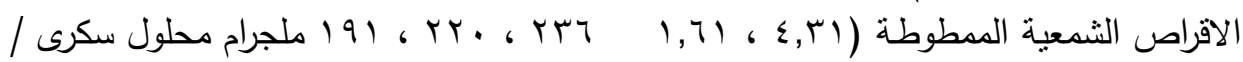

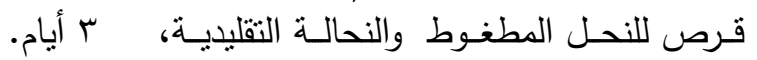

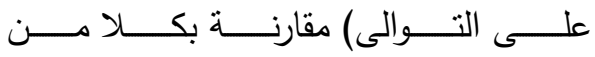
| ا.د محمد عطية عوبس تحكيم: ا.د أحمد علم حمعـه 